Berkala Ilmu Perpustakaan dan Informasi, Vol. 15, No. 1, Juni 2019 Hal. 101-113 DOI: $10.22146 /$ bip.38504

ISSN 1693-7740 (Print), ISSN 2477-0361 (Online)

Tersedia online di https://jurnal.ugm.ac.id/bip

\title{
Strategi pengelolaan jurnal akses terbuka menggunakan open journal system (OJS)
}

\author{
Tangguh Okta Wibowo \\ ${ }^{1}$ Kajian Budaya dan Media, Sekolah Pascasarjana Universitas Gadjah Mada \\ e-mail:tangguh.o.w@ugm.ac.id
}

Naskah diterima: 02 September 2018, direvisi: 15 Februari 2019, disetujui: 21 Februari 2019

\begin{abstract}
ABSTRAK
Pendahuluan. Studi ini berupaya untuk memetakan kerangka konseptual dalam memahami penerapan platform open journal system untuk jurnal akses terbuka. Pembahasan jurnal ilmiah di lingkungan akademik yang digunakan sebagai sumber rujukan sudah banyak dilakukan, akan tetapi pembahasan jurnal ilmiah sebagai objek kajian belum banyak dilakukan.

Metode Penelitian dan data analisis. Metode yang digunakan dalam studi ini adalah deskriptif analisis dengan menggunakan perspektif multidisiplin (teori prosumsi-produksi dan konsumsi) untuk memahami pengelolaan dan penerbitan jurnal ilmiah elektronik di era digital, serta memahami keunggulan dan kendala yang muncul.

Hasil dan Pembahasan. Hasil penelitian menunjukkan bahwa aspek untuk membantu memperkaya kerangka berpikir jika jurnal ilmiah hanya menerima artikel dari penulis untuk diterbitkan dan menjadi sumber rujukan saja. Studi ini menawarkan kerangka berpikir untuk memahami bahwa jurnal ilmiah di era digital ini sebaiknya juga membangun hubungan yang baik dengan penulis dan pembaca yang berpotensi menjadi calon penulis, serta mitra bestari.

Kesimpulan. Sudi ini mencoba menawarkan sebuah strategi pengelolaan jurnal akses terbuka agar secara konseptual dapat digunakan dalam memahami perkembangan jurnal ilmiah yang berkesinambungan, menjaga kualitas terbitan, dan membentuk komunikasi yang baik antara pengelola jurnal, penulis, pembaca, dan mitra bestari.
\end{abstract}

Kata Kunci: artikel ilmiah; jurnal akses terbuka; komunikasi; open journal system; sumber rujukan

\section{ABSTRACT}

Introduction. This study tries to map a conceptual framework in the application of open journal system as a platform for open access journals. Research on scientific journals used as sources of references has been widely conducted, however, more research is needed to understand scientific journals as the object of study.

Method and analysis data. This study uses descriptive analysis by using multi-discipline perspective (prosumption -production and consumption- theory) in understanding the management and publication for academic e-journal in digital era, also to review the benefits and the obstacles.

Results and Discussions. The results provide better understanding of how a scientific journal should work. This study offers a framework for understanding that scientific journals should also build good relationships with authors and readers who have the potential to become potential authors, and reviewers.

Conclusion. This study tries to offer a strategy for managing open access journals so that conceptually can be used in understanding the development of continuous scientific journals, maintaining the quality of publications, and forming good communication between journal managers, writers, readers and reviewers.

Keywords: communication; open access journal; open journal system; reference sources; scientific article 


\section{A. PENDAHULUAN}

Berdasarkan surat edaran dari Kementerian Riset, Teknologi, dan Pendidikan Tinggi Direktorat Jenderal Penguatan Riset dan Pengembangan (Ristek Dikti) tentang Akreditasi Terbitan Berkala Ilmiah Elektronik Tahun 2018 bahwa setiap jurnal diwajibkan untuk memiliki nomor ISSN (International Standard Serial Number) dalam versi cetak (pISSN) dan versi elektronik (e-ISSN) bila sebuah jurnal terbit dalam dua versi (Ristek Dikti, 2018a). Surat edaran ini mensyaratkan jika setiap jurnal didorong untuk memiliki versi elektronik agar dapat diakses secara online. Hal ini berarti mengharuskan setiap jurnal yang telah memiliki p-ISSN harus memiliki e-ISSN. Secara umum, bagi jurnal yang telah memiliki eISSN dapat menerbitkan jurnalnya dalam format online $(P D F)$ yang berarti jurnal ini dapat diakses lebih luas tanpa perlu berlangganan seperti jurnal cetak dan di sisi lain, biaya pengeluaran untuk mencetak jurnal dalam bentuk fisik dapat berkurang.

Jurnal elektronik (e-journal) dapat diterbitkan oleh perguruan tinggi, lembaga ilmiah, dan himpunan profesi di Indonesia (Ristek Dikti, 2018a). Untuk pengelolaan dan penerbitan jurnal ini dapat dilakukan dengan menggunakan platform open source yang dapat dipergunakan dan memfasilitasi segala kebutuhan penerbitan jurnal elektronik, seperti submission, peer-review, editing, publishing, subscription, dan lainnya. Dalam Permenristekdikti No.9 Tahun 2018 Tentang Akreditasi Jurnal Ilmiah (Ristek Dikti, 2018b) disebutkan bahwa pengelolaan terbitan ini dapat menggunakan aplikasi (platform) salah satunya adalah Open Journal System (OJS). OJS ini merupakan sebuah CMS (Content Management System) yang diperuntukkan untuk pengelolaan dan penerbitan jurnal yang dapat dioperasikan secara fleksibel dan dapat digunakan secara gratis.

Menurut pedoman Ristek Dikti (2018c:80) untuk aturan Pedoman Akreditasi Jurnal Ilmiah Tahun 2018, platform yang direkomendasikan adalah produk OJS dari Public Knowledge Project (PKP) yang beroperasi melalui kemitraan antara Fakultas Pendidikan di
University of British Columbia, Simon Fraser University Library, Sekolah Pendidikan di Stanford University, dan Pusat Studi di Kanada untuk penerbitan di Simon Fraser University. Perkembangan OJS semakin banyak dimanfaatkan oleh pengguna di seluruh dunia.

Lebih lanjut, keberadaan jurnal elektronik ini juga turut menimbulkan berbagai persoalan. Pertama, bagi pengelola jurnal diwajibkan untuk menguasai dasar-dasar dalam memahami pengelolaan dan penerbitan menggunakan OJS, karena semua proses dari pengiriman artikel dari penulis hingga artikel tersebut dinyatakan siap untuk terbit melalui aplikasi OJS. Oleh karena itu, Ristek Dikti harus mensosialisasikan dan mengadakan berbagai pelatihan bagi pengelola jurnal (admin, editor, dan mitra bestari). Ristek Dikti juga mensyaratkan setiap jurnal untuk pengajuan akreditasi demi menjaga jaminan mutu terbitan.

Kedua, kepemilikan pengetahuan dasar bagaimana mengirimkan artikel ilmiah di jurnal elektronik juga harus dikuasai penulis, karena setiap jurnal sekarang mendorong penulisnya untuk mengirimkan naskahnya melalui OJS dan bukan melalui email, sehingga penulis dapat secara mandiri memonitor semua proses terhadap naskah yang dikirimkan. Ketiga, bagi mitra bestari, mereka harus memiliki pengetahuan dasar OJS bagaimana cara untuk me-review sebuah artikel yang ditugaskan kepadanya, terutama bagi mitra bestari yang belum mengenal OJS dan bagaimana mengoperasikannya.

Pemaparan persoalan di atas merupakan ragam konsekuensi teknis jika dilihat dari sisi pengelola jurnal, penulis, dan mitra bestari. Oleh karena itu, studi ini bersifat orisinal dengan kebaruan yang ditawarkan yaitu mengenai pelaksanaan pengelolaan jurnal elektronik di lingkungan Universitas Gadjah Mada yang dapat diakses di laman https://jurnal.ugm.ac.id, khususnya dalam membangun komunikasi antar aktornya, yaitu penulis, pengelola jurnal, mitra bestari, dan pembaca/pelanggan. Pembahasan jurnal ilmiah di lingkungan akademik yang digunakan sebagai sumber rujukan telah banyak dilakukan, akan tetapi pembahasan jurnal ilmiah sebagai objek kajian belum banyak dilakukan, 
seperti penelitian sebelumnya dari Prijana dan Yanto (2018), Nur'aini (2015), Rahma (2017), Wang (2013), (McCabe \& Synder, 2015:453), dan Kumar dkk. (2009). Tujuan dari studi ini adalah berkontribusi untuk menawarkan sebuah kerangka konseptual dengan perspektif multidisiplin dari Ritzer (2013), teori prosumsi (produksi dan konsumsi) pada ranah disiplin ilmu perpustakaan, untuk memahami pengelolaan dan penerbitan jurnal ilmiah elektronik yang berkesinambungan dan membentuk komunikasi yang baik antara pengelola jurnal, penulis, pembaca, dan mitra bestari.

\section{B. TINJAUAN PUSTAKA \\ 1. Jurnal Akses Terbuka (Open Access Journal)}

Sebuah kekecewaan dari ilmuwan dan pustakawan, karena teknologi baru mungkin dapat menurunkan pengeluaran sebuah jurnal untuk biaya produksi dan distribusi, akan tetapi biaya langganan perpustakan masih mahal. Kekecewaan tersebut membawa sebuah model baru untuk jurnal akademik, yaitu akses terbuka (open access) (McCabe \& Synder, 2015). Akses terbuka (open access) telah meningkatkan momentum untuk sebuah model penerbitan ilmiah memungkinkan hasil penelitian dapat diakses gratis oleh komunitas dan dapat diakses secara publik di internet (Leptin, 2012). Selain itu, jurnal dengan akses terbuka memiliki beberapa keunggulan, karena peralatan digital ini mengubah sebuah mekanisme reproduksi dan pendistribusian berkas digital (Zysman, 2002; Wibowo, 2015), selanjutnya dapat dilihat di Tabel 1.

Di sisi lain, secara prosedural di tabel 1, Hall (2008) berpendapat jika jurnal elektronik dengan akses terbuka memiliki keunggulan lain, diantaranya (a) dapat dihubungkan pada latar belakang dan penelitian terkait, misalnya dapat dilampirkan $U R L$ atau alamat websitenya di blog, wiki dan web individu atau institusi; (b) membuat artikel jurnal dapat diakses di perangkat elektronik apa saja, dan dapat diakses di rumah, universitas, perpustakaan, atau sekolah, selama dua puluh empat jam sehari; (c) dapat digandakan sebanyak yang dibutuhkan.
Hal tersebut dapat dilakukan, karena semua file artikel dapat diakses secara online, sehingga pembaca hanya membutuhkan link artikel terkait untuk mengunduhnya (download); (d) dapat digunakan dengan mudah pada saat mengajar sebagai materi dengan melampirkan link artikel sebagai rujukan; (d) dapat dipromosikan dengan gratis. Melalui link/DOI (Digital Object Identifier) unik setiap artikel, penulis dapat mengirimkannya melalui email, sehingga keterbacaan menjadi lebih luas; (e) lebih berpotensi untuk meningkatkan feedback dan pengaruh yang kuat kepada pembaca atau calon penulis; (f) dapat membuat artikel ilmiah menjadi tersedia secara "permanen" di internet, sehingga penulis tidak perlu fokus kepada tulisannya yang mungkin bisa hilang seperti versi cetak; (g) penulis dapat dengan mudah dan cepat untuk memenuhi kewajibannya kepada pihak yang mendanai penelitiannya yang mengharuskan untuk membuat hasil penelitian dapat tersedia di open access platform.

\section{Skema Penerbitan Artikel Melalui Jurnal Elektronik}

Pemanfaatan OJS sebagai platform untuk mengelola terbitan secara online dan open access memang memiliki ragam keunggulan, tetapi di sisi lain, siklus penerbitan artikel juga harus dilakukan secara online dan semua tahapan proses penanganan artikel dari tahap awal, yaitu artikel yang dikirimkan oleh penulis hingga dinyatakan terbit terekam oleh sistem OJS. Untuk sistem OJS dapat dilihat di Gambar 1 .

\section{Siklus Pengelolaan dan Penerbitan Jurnal Elektronik}

Pengelolaan dan penerbitan jurnal secara elektronik turut mempengaruhi pola komunikasi sebelumnya, sehingga hal ini turut mengalami sebuah peralihan. Jika dahulu pengiriman artikel oleh penulis dapat dikirimkan melalui e-mail dan korespondensi selanjutnya melalui email, tetapi sekarang penulis harus registrasi dan memiliki akun di jurnal OJS sebagai author agar dapat mengirimkan artikel dan kemudian memonitornya secara mandiri keseluruhan 
prosesnya. Begitu pula dengan pengelola jurnal dan mitra bestari, mereka harus juga memiliki akun di OJS.

Baik pengelolaan dan penerbitan di jurnal cetak ataupun jurnal elektronik memiliki sebuah siklus yang sama (seperti di Gambar 1), elemen yang penting sebagai aktor adalah pembaca, penulis, pengelola jurnal, dan mitra bestari. Menurut Ritzer (2013), di dalam proses produksi terdapat proses konsumsi, sehingga tidak ada proses yang murni produksi saja tanpa adanya konsumsi, begitu pula sebaliknya dan kedua proses ini selalu melingkupi. Teori prosumsi yang dikembangkan oleh Ritzer, terutamanya -meski tidak terbatas- pada peranan user di internet, Web 2.0 (di mana user dapat memproduksi sekaligus mengonsumsi konten di website yang memfasilitasi mereka untuk membuat konten, seperti Wikipedia, Facebook, Youtube, Linux, Amazon, dll). Hubungan antara produsen dan konsumen di era digital juga turut berubah, yaitu fokus pada user yang aktif sebagai produser dan konsumer konten atau disebut sebagai prosumer (Ritzer dan Jurgenson, 2010). Xie (2005), berpendapat prosumsi sebaiknya dapat dipahami sebagai sebuah proses. Menurut Wibowo (2015), aktor yang aktif pada proses produksi-konsumsi tidaklah pasif dan dalam bahasan ini sebaiknya dalam konteks prosumsi merujuk sebagai prosumer. Jika dianalogikan, prosumsi ini layaknya koin logam yang dengan dua sisi yang tidak terpisahkan, tetapi menjadi satu kesatuan. Studi ini melakukan limitasi dalam mempergunakan perspektif prosumsi ini untuk melihat prosumer (atau selanjutnya aktor) yang aktif pada saat memerankan posisinya pada penerbitan jurnal. Untuk detail proses prosumsi (produksi-konsumsi) ini dapat dilihat di Gambar 2.

Studi ini mencoba mengadopsi teori prosumsi atau singkatan dari produksi dan konsumsi untuk dapat diaplikasikan dalam memahami siklus penerbitan jurnal elektronik ini. Karena hal ini dapat berdampak pada kualitas terbitan dari jurnal tersebut atau jika terjadi sebuah permasalahan, misalnya terjadi keterlambatan penanganan artikel yang masuk, proses review yang lama, atau proses revisi yang lama dari penulis akan memberikan dampak pada keteraturan jalannya proses penerbitan.

\section{METODE PENELITIAN}

Metode yang digunakan dalam studi ini adalah deskriptif analisis. Data disajikan dalam bentuk deskripsi dan dianalisis menggunakan kerangka teoritis. Untuk metode pengumpulan data, studi ini mencoba mendialogkan penelitian terdahulu, teori, dan review dari pengelolaan dan penerbitan jurnal elektronik menggunakan platform Open Journal System (OJS). Untuk kumpulan jurnal tersebut diambil dari jurnal elektronik di lingkungan Universitas Gadjah Mada yang dapat diakses di laman website https://jurnal.ugm.ac.id. Statistik jurnal ini dapat dilihat di Tabel 2. Metode survei digunakan untuk memperoleh karakteristik suatu jurnal secara spesifik. Metode survei dalam konteks ini pada umumnya dipergunakan untuk jenis penelitian deskriptif yang bertujuan mendeskripsikan dan menjelaskan gambaran di lapangan untuk mengkaji populasi besar atau kecil untuk membuat taksiran yang akurat mengenai karakteristik-karakteristik keseluruhan populasi (Widodo, 2012). Data kuantitatif dari hasil survei diperoleh dari responden dari penulis yang pernah menulis di jurnal lingkungan UGM, yaitu jurnal Teknosains (11 responden) dan jurnal Kawistara (18 responden) untuk menggambarkan secara umum tata kelola kedua jurnal yang diterbitkan oleh lingkungan Sekolah Pascasarjana UGM dan telah terakreditasi Sinta (Science and Technology Index) yang diinisiasi Direktur Jenderal Penguatan Penelitian dan Pengembangan, Kementerian Riset, Teknologi, dan Pendidikan Tinggi Republik Indonesia, dengan peringkat 2 .

\section{HASIL DAN PEMBAHASAN \\ 1. Jurnal Elektronik sebagai Sumber Rujukan \\ Di bagian tinjauan pustaka telah dipaparkan} jika di dalam pengelolaan dan penerbitan jurnal elektronik terdapat beberapa aktor kunci, yaitu penulis, pengelola jurnal, dan mitra bestari. Mereka berperan dalam terjadinya sebuah siklus yang berkesinambungan layaknya sebuah 
sirkuit. Bila dilihat dari awal hingga keseluruhan prosesnya, yaitu artikel dari penulis masuk, diproses oleh editor, di-review oleh mitra bestari, kemudian diteruskan kepada penulis untuk direvisi, lalu keputusan akhir apakah artikel akan diterima atau ditolak, hingga proses editing oleh editor dan diterbitkan di jurnal.

Lebih lanjut, perlu dipertimbangkan juga bahwa keberadaan pembaca sangat penting di sini. Kemudian artikel yang telah terbit ini akan diakses oleh pembaca yang juga merupakan calon penulis di jurnal tersebut. Berdasarkan Pedoman Akreditasi Jurnal Ilmiah, pengunjung (visitors) website jurnal dalam konteks ini adalah pengunjung yang berperan sebagai pembaca menjadi salah satu unsur penilaian akreditasi jurnal ilmiah untuk mengukur keluasan persebaran jurnal (Ristek Dikti, 2018c).

Jika dilihat dari sisi pembaca, materi yang dapat diakses secara online berdampak positif terhadap peningkatan prestasi mahasiswa (Lestari dkk, 2015; Prijana dan Yanto, 2018). Secara umum, mahasiswa lebih menggunakan database jurnal elektronik dibandingkan dengan jurnal cetak, karena penelusuran jurnal elektronik lebih cepat dan mudah. Kedua, jurnal elektronik lebih mutakhir (up to date) (Nur'aini, 2015 ). Penelitian dari Rahma (2017) menyebutkan jika jurnal menjadi bagian dari rujukan yang mutakhir untuk penulisan tesis jurusan Psikologi UGM di tahun 2012. Penerapan ini juga dapat dilihat dari sisi penerbit, yaitu beberapa jurnal mensyaratkan penggunaan referensi di artikel lebih kepada jurnal, salah satunya jurnal Berkala Ilmu Perpustakaan dan Informasi menekankan penggunaan jurnal sebagai sumber rujukan sebesar $80 \%$ di daftar pustaka dan diterbitkan pada kurun waktu sepuluh tahun terakhir.

Beberapa ulasan hasil penelitian di atas menunjukkan jika pembaca juga memiliki peranan penting dalam kemajuan jurnal elektronik. Jurnal elektronik yang dapat diakses secara online dapat membuka sebuah keterbukaan dan persebaran hasil penelitian dalam bentuk artikel lebih dapat dirasakan manfaatnya untuk perkembangan penelitian selanjutnya. Menurut Wang (2013), jurnal dengan akses terbuka secara efektif mudah untuk digunakan dan diakses. Terlebih, jurnal ini dapat digunakan sebagai ruang untuk terbukanya sebuah debat dan komunikasi ilmiah yang aktif. Hal ini mendukung terciptanya sebuah model eksternalitas bilateral, yaitu pembaca memperoleh keuntungan dari apa yang dibaca dan penulis mendapat keuntungan dari artikelnya yang diakses tersebut (McCabe dan Synder, 2015). Hal ini menggarisbawahi jika pembaca yang mengakses jurnal tersebut membuka sebuah peluang untuk menjadi calon penulis di jurnal yang mereka akses.

Jurnal akses terbuka dapat menjadi sumber rujukan baik bagi mahasiswa, peneliti, dan institusi. Menurut Gibson dan Ruotolo (2013; Wibowo, 2015), melalui format PDF ini, mahasiswa dapat mengakses di mana saja, misalnya di halte bus pada jam 1 pagi daripada pergi ke ruang buku. Shiratuddin (2005; Wibowo, 2015) menambahkan jika kehadiran format PDF (e-book) di level universitas memiliki dampak yang positif. Kumar dkk. (2009) berpendapat jika respon pustakawan terhadap format artikel dalam bentuk portable document format (PDF) menunjukkan jika 60\% pustakawan mempunyai pandangan bahwa format e-book (PDF) mudah untuk diakses dengan mengadopsi teknologi baru dan $90 \%$ diantaranya berpendapat jika format tersebut hanya memerlukan sedikit ruang dan tidak perlu banyak penggandaan. Banyak pembaca dapat mengakses dan membaca secara bersamaan dan tidak diperlukan pemeliharaan fisik. Oleh karena itu, pembaca tidak hanya dibatasi pada pembaca sebagai individu, tetapi juga institusi, misalnya perpustakaan pusat atau fakultas yang memesan dan berlangganan jurnal cetak sebagai koleksi. Tentu saja, hal ini juga dapat menjadi peluang untuk menarik lebih banyak pembaca di kalangan akademis yang kesulitan dalam mengakses jurnal tertentu.

\section{Penerapan Konsep Prosumsi dalam Pengelolaan Jurnal Elektronik}

Menilik konsep prosumsi (produksi dan konsumsi), tidak dapat dipungkiri jika setiap aktor yang terlibat di putaran jurnal elektronik 
ini juga merupakan prosumer (atau selanjutnya aktor) yang aktif, sehingga dengan menerapkan konsep ini, secara tidak langsung dapat mengubah mindset (pola pikir) bahwa jurnal hanyalah bertindak sebagai sebuah wadah yang secara pasif menerima artikel hasil penelitian penulis saja. Akan tetapi sebagai sumber rujukan, sebaiknya jurnal elektronik yang dapat diakses secara online dapat mempermudah terciptanya sebuah wadah yang dapat mengakomodasi segala kebutuhan. Pengelola jurnal ilmiah juga perlu menjaga komunikasi yang baik antara penulis, pembaca/pelanggan jurnal, pengelola jurnal, dan mitra bestari. Jika dilihat dari perspektif pengguna, sistem elektronik dan online ini harus mudah untuk diakses dan perkembangannya harus berdasarkan pemanfaatan kemajuan teknologi yang dapat diakses oleh sebagian besar komunitas akademik ( Ngah, Fong, dan Abdullah, 2005:61).

Konsep prosumsi ini dapat diterapkan pada proses penerbitan artikel di jurnal ilmiah secara online. Hal ini dapat dilihat dari sisi penulis, pengelola jurnal, dan mitra bestari. Penulis tidak hanya memproduksi artikel ilmiah yang nantinya dikirimkan ke jurnal, tetapi juga dalam proses konsumsi, yaitu merevisi hasil review dari masukan tim editor dan mitra bestari. Pengelola jurnal juga 'mengonsumsi' artikel yang masuk ke jurnal dan kemudian diproses untuk dikembalikan kepada penulis agar direvisi, dan memproses kembali artikel akhir yang dinyatakan diterima untuk diproduksi dalam bentuk terbitan. Mitra bestari juga demikian, mereka menerima artikel dari pengelola jurnal untuk di-review (proses konsumsi), kemudian artikel tersebut diberikan masukan dan komentar agar dapat direvisi oleh penulis (proses produksi) dan dikembalikan kepada pengelola jurnal untuk diproses selanjutnya.

Hal ini mengindikasikan jika setiap aktor memiliki peran aktif dalam menciptakan sebuah suasana yang kondusif untuk menunjang kinerja penerbitan jurnal elektronik tersebut. Untuk lebih jauh, proses ini dapat dilihat lebih jauh di Gambar 3.
Skema di Gambar 3 menunjukkan jika posisi e-journal menjadi pusat komunikasi baik dari penulis, pengelola jurnal, mitra bestari atau pembaca/pelanggan jurnal. Alat komunikasi yang biasanya disediakan oleh jurnal elektronik ini dapat dilihat di bagian laman about dan pilih contact. Komunikasi ini dapat dilakukan melalui email dan nomor telepon yang dilampirkan. Pola skema di gambar 3 akan terkendala sebuah permasalahan ketika misalnya penulis yang tidak memiliki waktu untuk membuka emailnya atau hasil review yang dikirimkan kepada penulis tidak tersampaikan, dikarenakan fitur OJS yang terkadang error dalam mengirimkan email dan/atau masuk dalam folder spam di beberapa penyedia fasilitas email. Skema ini juga memiliki permasalahan, misalnya mitra bestari belum memiliki kemampuan dasar dalam menguasai OJS atau mereka tidak mengetahui jika sedang ditugaskan untuk me-review artikel, karena mereka tidak membuka email.

Oleh karena itu, langkah awal yang perlu untuk dilengkapi adalah setiap jurnal melampirkan segala informasi yang diperlukan bagi penulis untuk melakukan proses submission, termasuk panduan penulisan, format penulisan, etika penerbitan, terindeks oleh lembaga pengindeks, dan termasuk biaya publikasi (jika ada). Kemudian, sebuah panduan juga perlu dibuat kepada mitra bestari bagaimana tata cara untuk me-review dan membantu mitra bestari yang kesulitan untuk mengakses OJS, sehingga hal ini memudahkan secara prosedural untuk proses terbitan.

Lebih jauh, jika e-journal hanya dijadikan sebagai sebuah wadah untuk menjalin komunikasi antar aktornya, maka tidak jarang terjadi sebuah keterlambatan terbitan. Hal tersebut dapat disebabkan oleh beberapa faktor, misalnya keterlambatan penulis merevisi karena tidak membuka emailnya, mitra bestari yang tidak menguasai fitur OJS dan tidak membuka emailnya, atau pihak pembaca/pelanggan yang ingin membeli jurnal tidak mendapatkan jawaban atas invoice yang dikirimkan melalui email. Dengan demikian, untuk mengatasi persoalan seperti itu, tulisan ini mencoba 
memaparkan sebuah strategi dengan menerapkan skema prosumsi diantara aktornya, sehingga tercipta sebuah pola komunikasi aktif yang diharapkan dapat terjalin sebuah hubungan yang baik.

\section{Strategi Pengelolaan dan Penerbitan Jurnal Elektronik}

Menurut Junandi (2018), website jurnal merupakan representasi profesionalisme atas pengelolaan suatu jurnal. Hal ini selaras dengan kualitas jurnal yang dinilai oleh calon penulis, karena tampilan yang menarik dan informasi yang selalu diperbaharui merupakan dasar untuk menjadikan sebuah website yang unggul (excellence). Akan tetapi kualitas jurnal tidak hanya dinilai dari website jurnal, menurut Wang (2013), kesuksesan dan kualitas dari jurnal akan tergantung pada penulis dan editor, di mana mereka akan bekerja bersama-sama untuk memastikan sebuah kualitas yang tinggi dan keketatan editorial yang akhirnya dapat dicapai. Pengiriman artikel secara online dapat dilakukan di mana saja, tetapi kualitas dari artikel yang dikirimkan menjadi problematis (Chun dan Thompson, 2010). Hal ini dapat dijadikan sebuah paradigma yang baik untuk mengantisipasinya dengan menciptakan suasana komunikasi yang aktif, termasuk komunikasi yang efektif dan cepat antara penulis dan editor akan terjalin sebuah kolaborasi untuk menjaga kualitas artikel yang tinggi. Menurut Wibowo (2015), proses prosumsi ini merupakan bagian dari sebuah rangkaian aktivitas yang berkesinambungan layaknya sebuah sirkuit dan terjadi sebuah kolaborasi di dalam prosesnya. Jika melihatnya sebagai sebuah sirkuit, maka konsekuensinya setiap elemen memiliki bagian yang penting, sehingga tidak dapat dihilangkan atau dikurangi.

Tabel 2 memuat data dari seluruh jurnal elektronik di lingkungan Universitas Gadjah Mada yang dapat diakses di laman https://jurnal.ugm.ac.id dengan total jurnal elektroniknya adalah $\mathrm{n}=77$ (diakses pada tanggal 30 Oktober 2018). Berdasarkan data dari tabel 2 dapat dilihat jika hampir seluruh jurnal elektronik menggunakan email sebagai alat komunikasi dengan penulis dan hanya 1 jurnal yang belum/ jurnal baru, sehingga tampilannya masih kosong, yaitu jurnal deskripsibahasa.

Hal mendasar yang membedakan alat komunikasi email, jurnal tradisional dan jurnal elektronik memperlakukannya berbeda. Pada jurnal tradisional (sebelum ada fitur OJS) semua proses pengiriman artikel dan distribusi artikel kepada mitra bestari mempergunakan email, sehingga email memiliki peranan penting untuk memperlancar proses terbitan. Di sisi lain, jurnal elektronik mempergunakan email bukan lagi menjadi alat satu-satunya untuk distribusi artikel, setelah jurnal elektronik memanfaatkan fitur OJS ini. Peranan email di jurnal elektronik mulai beralih peranannya menjadi alat komunikasi. Selain itu, penggunaan email menjadi penting bagi setiap aktor yang terlibat, karena setiap akun yang terdaftar harus memiliki email untuk dapat didaftarkan dan setiap pemberitahuan untuk proses atau hasil review baik dari editor dan mitra bestari juga melalui email. Hal ini juga dapat dilihat persentase $98,7 \%$ jurnal elektronik di lingkungan UGM menggunakan email sebagai alat komunikasi yang dapat diakses di laman kontak masing-masing website (bisa diakses di https://jurnal.ugm.ac.id/nama jurnal/about/ contact).

Keterbukaan dalam penelitian akan menimbulkan dampak yang positif bagi Indonesia, karena kolaborasi dan jejaring akan menjadi lebih luas jika setiap hasil riset, termasuk data, dapat diakses secara terbuka. Kemudian, pemanfaatan jalur komunikasi di era internet dapat dimaksimalkan untuk meningkatkan dampak penelitian (Irawan, dkk., 2017). Hal ini dapat dilakukan karena semakin mudahnya berkomunikasi secara online, misalnya penggunaan nomor telepon yang terhubung dengan aplikasi Whatsapp. Pencantuman nomor telepon kantor dengan persentase $29,8 \%$ menunjukkan jika telepon kantor memiliki kemungkinan sebagai alat komunikasi antar aktor, tetapi alat komunikasi ini terbatas dengan mengikuti jam kantor.

Lebih jauh, fitur Whatsapp ini dapat dipergunakan sebagai sarana untuk 
memperlancar akses komunikasi antara penulis, pengelola jurnal, mitra bestari, dan pembaca/pelanggan seperti di Gambar 4. Strategi pemanfaatan penggunaan Whatsapp dalam proses komunikasi ini telah diterapkan oleh beberapa jurnal, misalnya jurnal Kawistara dapat dilihat di Gambar 5. Praktik ini telah diterapkan oleh jurnal Kawistara mulai tahun 2018. Sebanyak 18 responden yang pernah menulis di jurnal Kawistara dan 11 responden di jurnal Teknosains memilih sangat terbantu (dari pilihan tidak terbantu, cukup terbantu, terbantu, dan sangat terbantu) dengan tingkatan 100\% bagi penggunaan Whatsapp untuk mempercepat respons atas pertanyaan dari penulis terkait status naskah mereka.

Studi kasus yang telah diterapkan oleh jurnal Kawistara dan jurnal Teknosains saat menjalin komunikasi, baik dari luar lingkup jurnal, misalnya seperti penulis yang menanyakan bagaimana cara untuk mengirim artikel jurnal atau menanyakan tema terbitan berikutnya, kapan issue terbaru terbit, atau pelanggan jurnal yang ingin membeli dan berlangganan jurnal tersebut versi cetak. Oleh karena itu, pengelola jurnal harus memiliki sebuah strategi untuk mengantisipasi hal tersebut.

Lebih jauh, dengan mengubah pola pikir dan mempertimbangkan setiap aktor memiliki peran yang aktif, maka seperti yang digambarkan di gambar 4 bahwa masingmasing aktor terjadi hubungan timbal balik (feedback) yang aktif. Batasan antar aktor untuk berkomunikasi secara langsung dengan pengelola jurnal menjadi kabur atau dapat dihilangkan, yaitu melalui staff yang aktif berkomunikasi dengan penulis/pembaca. Hal ini dapat membuat sebuah jurnal elektronik dapat mendekatkan diri juga dengan penulis dan pembaca yang berpotensi juga menjadi penulis di jurnal tersebut.

Terakhir, sebuah pendapat yang menarik dari Collins (2010) bahwa praktik mengonsumsi selalu berkembang sejalan dengan perkembangan teknologi baru, termasuk pola distribusinya. Hal ini mengindikasikan jika teknologi yang digunakan sekarang ini masih bersifat sementara, artinya di masa depan, pemanfaatan fitur-fitur yang baru dalam platform OJS juga turut dikembangkan, termasuk dengan produsen yang selalu memperbaharui produknya, misalnya dirilisnya OJS dengan versi terbaru (versi 3).

Selain pengetahuan pengelola jurnal yang perlu ditingkatkan secara komprehensif dan berkesinambungan dengan mengikuti berbagai pelatihan, misalnya pelatihan OJS, DOI, indikasi jurnal, manajemen penerbitan, dan internasionalisasi jurnal ilmiah (Junandi, 2018), tentu saja hal ini juga mempengaruhi aktor yang mempergunakan OJS untuk selalu memperbaharui pengetahuannya baik secara mandiri atau mengikuti beberapa pelatihan. Oleh karena itu, dengan memanfaatkan alat komunikasi yang digunakan oleh jurnal Kawistara dan jurnal Teknosains ini adalah sebagai upaya untuk menjembatani penulis dan mitra bestari yang mengalami kendala pada saat mengakses fitur OJS, sehingga dapat meminimalisir kendala yang ada pada saat penerapan jurnal elektronik ini.

\section{E. KESIMPULAN}

Berbagai keunggulan pemanfaatan jurnal elektronik sebagai platform untuk pengelolaan dan penerbitan sebuah jurnal dengan menggunakan fitur OJS, meskipun demikian secara tidak langsung masih menyisakan beberapa kendala, yaitu pengakses jurnal diharuskan memiliki kemampuan dasar dalam mengoperasikan jurnal elektronik. Di masa peralihan jurnal tradisional yang kini menjadi jurnal elektronik turut menghadirkan beberapa persoalan yang bersifat teknis, di mana dahulu proses penerbitan artikel pola komunikasinya mempergunakan email atau dokumen fisik, sekarang semua prosesnya dilakukan secara online. Sebuah tuntutan kepada tidak hanya pengelola jurnal untuk menguasai sistem OJS, tetapi juga di sisi lain, penulis, mitra bestari, dan calon penulis juga harus menguasai bagaimana secara prosedural jurnal elektronik bekerja.

Studi ini berkontribusi untuk memaparkan jurnal elektronik sebagai objek kajian studi dan secara prosedural bagaimana keunggulan dan permasalahan yang muncul dikarenakan penggunaan sistem OJS. Selanjutnya, studi ini 
menawarkan strategi yang dapat digunakan untuk memahami perkembangan jurnal ilmiah yang berkesinambungan. Kemudian upaya menjalin komunikasi yang baik antar penulis, pengelola jurnal, mitra bestari, dan pembaca/pelanggan berposisi sebagai prosumer yang memiliki peranan penting pada proses penerbitan artikel di jurnal ilmiah. Terakhir, sebuah strategi dalam memaksimalkan penggunaan fitur Whatsapp untuk memfasilitasi komunikasi tersebut, karena di era digital ini peralatan komunikasi juga turut bergeser menjadi lebih mobile. Hal ini dapat dijadikan sebuah strategi oleh jurnal elektronik untuk mendekatkan diri dengan penulis dan pembaca yang berpotensi juga menjadi penulis pada terbitan selanjutnya.

\section{DAFTAR PUSTAKA}

Chun, D. M. dan Thompson, I. (2010). Issues in publishing an online, open-access CALL journal. The Modern Language Journal, 94(4), 649-651.

Collins, S. (2010). Digital fair: prosumption and the fair use defence. Journal of Consumer Culture, 10(1), 37-55.

Hall, G. (2008). Digitize this book!: The politics of new media, or why we need open access now, United States: University of Minnesota Press.

Irawan, D. E., Rachmi, C. N., Irawan, H., Abraham, J., Kusno, K., Multazam, M. T., Rosada, K. K., Nugroho S. H., Kusumah, G., Holidin, D., Aziz, N. A. (2017). Penerapan open science di Indonesia agar riset lebih terbuka, mudah diakses, dan meningkatkan dampak saintifik. Berkala Ilmu Perpustakaan dan Informasi, 13(1), 25-36.

Junandi, S. (2018). Pengelolaan jurnal elektronik bidang perpustakaan menuju jurnal terakreditasi. Pustabiblia. Journal of Library and Information Science, 2(1), 119136.

Kumar, S., Agarwal, D. K., Lijhara, S. K., \& Tapkir, S. (2009). E-books: readers, librarians and publishers perspective. Paper dipresentasikan di Proceedings of the International Conference on Academic Libraries (pp 124-129).
Leptin, M. (2012). Editorial: Open access: Pass the buck. Science, 355(6074), 1279.

Lestari, E. P., Nupikso, G., dan Riyani, E. I. (2015). Pengaruh penggunaan bahan ajar online terhadap prestasi mahasiswa Universitas Terbuka. Jurnal Pendidikan Terbuka dan Jarak Jauh, 16(1),1-9.

McCabe, M. J \& Snyder, C. M. (2005). Open access and academic journal quality. The American Economic Review, 95(2), 453458.

Ngah, W. A., Fong, A. T. \& Abdullah, A. (2005). E-journal publishing in Malaysia: From single journal system to publishing through a host. Information Development, 21(1), 53-65.

Nur'aini. (2015). Perbandingan pemanfaatan jurnal tercetak dengan jurnal elektronik untuk kebutuhan informasi mahasiswa di perpustakaan Universitas Sumatera Utara cabang kedokteran. Berkala Ilmu Perpustakaan dan Informasi, 11(2), 36-43.

Prijana \& Yanto, A. (2018). Analisis hubungan prestasi akademik mahasiswa dengan akses sumber informasi. Berkala Ilmu Perpustakaan dan Informasi, 14(1), 87-94.

Rahma, A. A. (2017). Pemanfaatan jurnal psikologi dalam penyusunan tesis mahasiswa psikologi UGM tahun 2012 kajian analisis sitiran. Berkala Ilmu Perpustakaan dan Informasi, 13(1), 12-24.

Ristek Dikti. (2018a). Akreditasi terbitan berkala ilmiah elektronik tahun 2018 . Kementerian Riset, Teknologi, dan Pendidikan Tinggi Direktorat Jenderal Penguatan Riset dan Pengembangan. Diakses 14 Febuari 2019 dari https://ristekdikti.go.id/.

Ristek Dikti. (2018b). Permenristekdikti nomor 9 tahun 2018 tentang akreditasi jurnal ilmiah. Kementerian Riset, Teknologi, dan Pendidikan Tinggi Direktorat Jenderal Penguatan Riset dan Pengembangan. Diakses 14 Febuari 2019 dari http://ristekdikti.go.id/. 
Ristek Dikti. (2018c). Pedoman akreditasi jurnal ilmiah 2018. Kementerian Riset, Teknologi, dan Pendidikan Tinggi Direktorat Jenderal Penguatan Riset dan Pengembangan. Diakses 14 Februari 2019 dari http://arjuna2.ristekdikti.go.id.

Ritzer, G. dan Jurgenson, N. (2010). Production, Consumption, Prosumption: The nature of capitalism in the age of the digital 'prosumer' Journal of Consumer Culture, 10(1), 13-36.

Ritzer, G. (2013). Prosumption: Evolution, revolution, or eternal return of the same? Journal of Consumer Culture, 14(1), 1-22.

Shiratuddin, N. (2005). E-Books in higher education: Technology, e-marketing prospects, and pricing strategy. Journal of Electronic Commerce in Organizations, 3(2), 1-16.
Wang, Z. (2013). Introducing systems science and control engineering: An open access journal. Systems Science and Control Engineering: An Open Access Journal, 1(1), 1-1.

Wibowo, T. O. (2015). Studi prosumption ebook dalam bingkai sirkuit budaya (fenomena e-book gratis dalam situs membacacepat.com) (Tesis). Diakses dari Sekolah Pascasarjana Universitas Gadjah Mada.

Widodo. (2012). Cerdik Menyusun Proposal Penelitian Skripsi, Tesis, dan Disertasi. Jakarta: Magna Script Publishing.

Xie, C. (2005). Trying to prosume: Toward a perspective on prosumption (Disertasi). Diakses dari Universitas Norges Handelshøyskole.

Zysman, J. (2002). Production in a digital era: Commodity or strategic weapon?". BRIE Working Paper 147. 


\section{DAFTAR TABEL}

Tabel 1. Keunggulan Jurnal Akses Terbuka

\begin{tabular}{|c|c|}
\hline No. & Keunggulan \\
\hline 1 & Persebaran artikel dapat lebih luas dan dapat diakses lebih banyak pembaca. \\
\hline 2 & Dapat dimonitor keterbacaannya dengan memonitor pengunjung per hari/per klik di website. \\
\hline 3 & $\begin{array}{l}\text { Membuat penulis lebih mudah untuk mensitasi da n bagi pembaca mudah untuk mengakses artikel } \\
\text { untuk dibaca. }\end{array}$ \\
\hline 4 & $\begin{array}{l}\text { Secara virtual dapat menampilkan hypermedia, yaitu dengan format elektronik dapat menampilkan } \\
\text { suara, gambar, video dan web-based software programs. }\end{array}$ \\
\hline 5 & $\begin{array}{l}\text { Lebih cepat prosesnya untuk lalu lintas nas kah. Publikasi online dapat mempercepat komponen } \\
\text { tertentu mulavci dari proses pengiriman hingga penerbitan artikel (submission-to-publication } \\
\text { cycle). }\end{array}$ \\
\hline 6 & Biaya produksi yang lebih murah. \\
\hline 7 & $\begin{array}{l}\text { Fleksibilitas lokasi editor dan staff editorial. Hal ini dapat terj adi karena semua prosesnya dilakukan } \\
\text { secara online, dan tidak perlu terpaku pada sebuah lokasi tertentu. }\end{array}$ \\
\hline 8 & Artikel di jurnal akses terbuka kemungkinan dibaca dan disitasi lebih tinggi. \\
\hline 9 & Pembaca tidak perlu untuk berafiliasi dengan petugas perpustakaan untuk mengakses jurnal. \\
\hline 10 & $\begin{array}{l}\text { Jurnal akses terbuka memberikan manfaat bagi institusi yang tidak dapat berlangganan jurnal } \\
\text { karena biaya langganannya yang mahal, sehingga dapat mengaksesnya }\end{array}$ \\
\hline
\end{tabular}

Sumber Chun dan Thompson ( 2010)

Tabel 2. Alat Komunikasi E-journal UGM

\begin{tabular}{clccl}
\hline No & \multicolumn{1}{c}{ Alat komunikasi } & Jumlah & Persentase & \multicolumn{1}{c}{ Keterangan } \\
\hline 1 & Kosong (jurnal baru) & 1 & $1,2 \%$ & Jurnal Deskripsi Bahasa \\
2 & Email & 76 & $98,7 \%$ & Bisa diakses di laman kontak \\
3 & Email, telepon kantor & 23 & $29,8 \%$ & misalnya https:/jurnal.ugm.ac.id/ \\
4 & Email, telepon kantor, & 45 & $58,4 \%$ & nama jurnal/about/contact \\
& Hp/whatsapp & & & \\
5 & Dilengkapi maps/google maps & 57 & $74 \%$ & \\
\hline
\end{tabular}

Sumber: dokumentasi pribadi (2018) 


\section{DAFTAR GAMBAR}

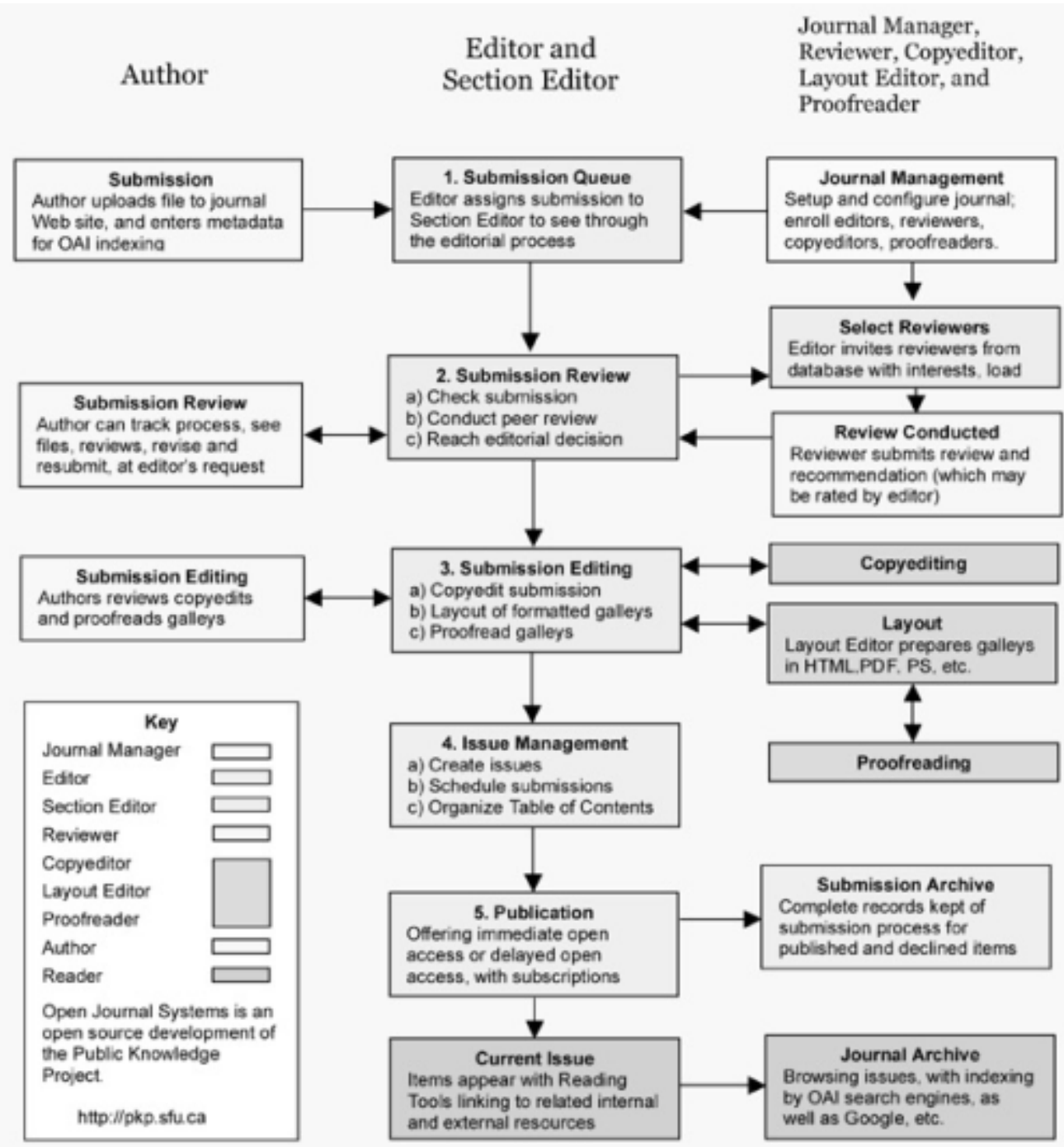

Gambar 1. Proses Editorial dan Penerbitan Melalui OJS

(Sumber gambar: Skema Sistem OJS Jurnal Kawistara)

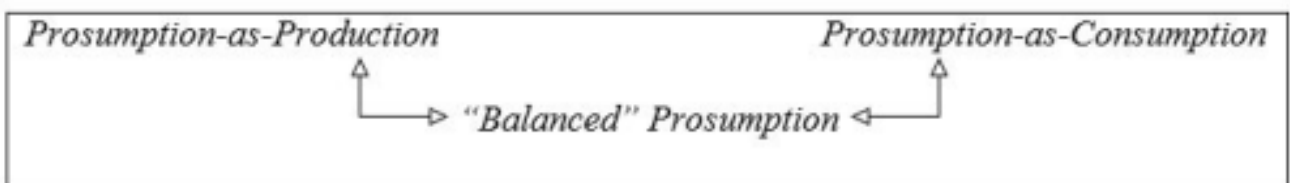

Gambar 2. Rangkaian prosumsi (Sumber: Ritzer, 2013) 


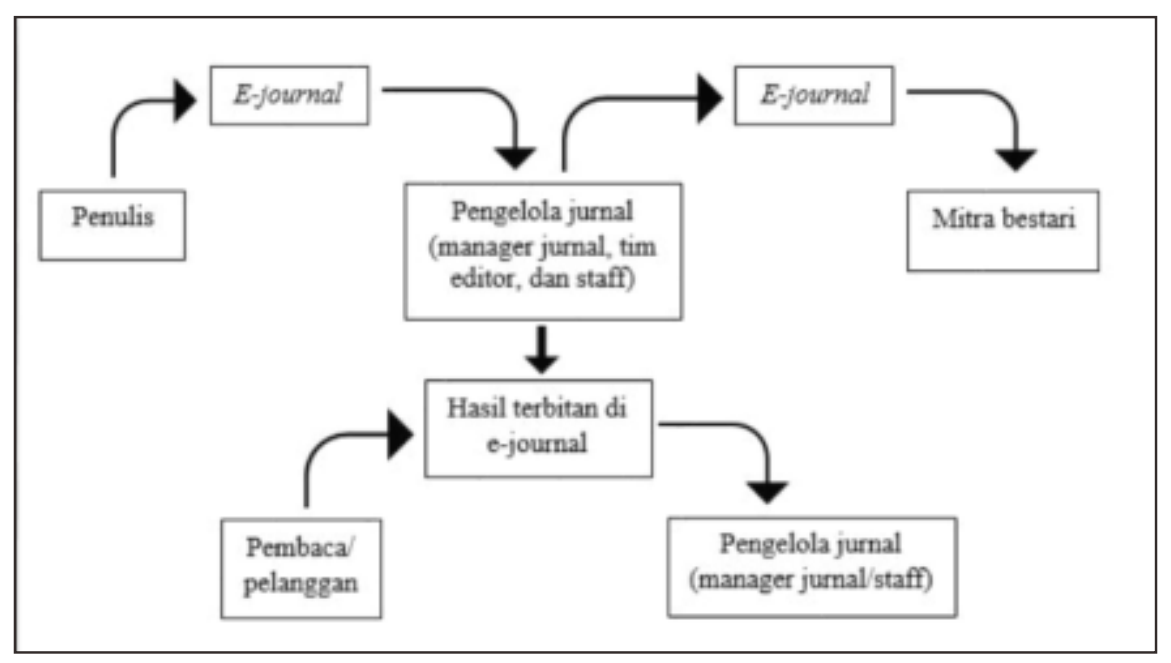

Gambar 3. Skema Pengelolaan dan Penerbitan Jurnal Elektronik

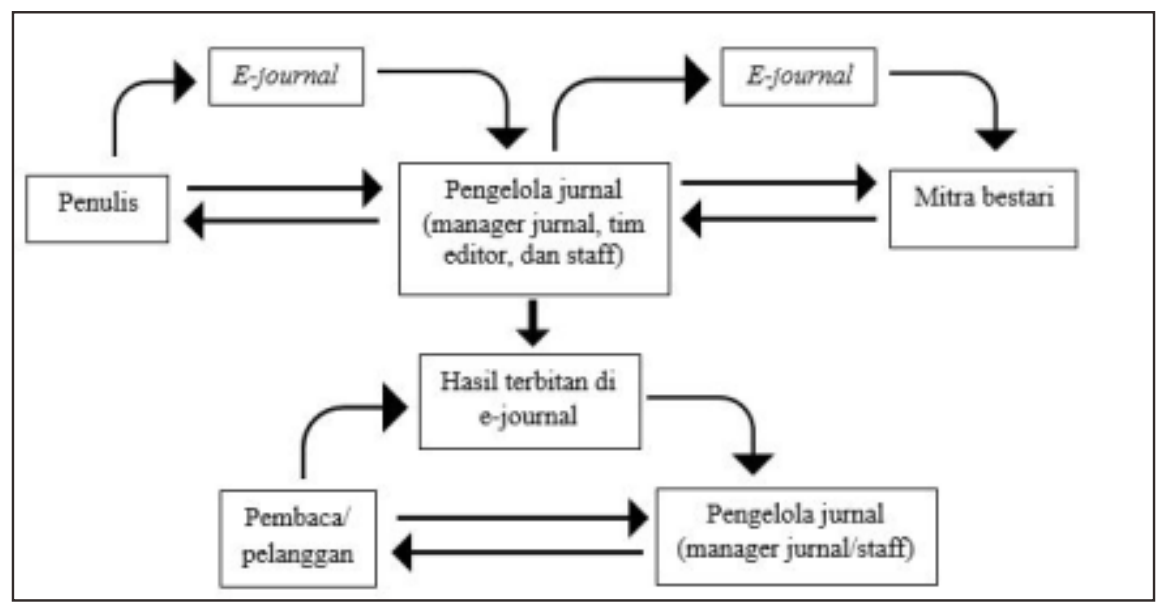

Gambar 4. Skema Prosumsi Pengelolaan dan Penerbitan Jurnal Elektronik 